Original article

\title{
ISOLATION OF BRUCELLA MELITENSIS STRAINS FROM SYRIAN BOVINE MILK SAMPLES
}

\author{
A. AL-MARIRI \\ Department of Molecular Biology and Biotechnology, Atomic Energy Commission, \\ Damascus, Syria
}

\begin{abstract}
Summary
Al-Mariri, A., 2015. Isolation of Brucella melitensis strains from Syrian bovine milk samples. Bulg. J. Vet. Med., 18, No 1, 40-48.

Brucellosis is a worldwide zoonotic disease that still constitutes a major public health problem in Syria. In the current study, Brucella has been isolated from cow milk samples and typed by both molecular and conventional techniques. Over a 6-year period (2002-2007) 2372 milk samples were collected from Syrian cow herds. The milk ring test (MRT) was performed where $57 \%$ of samples were found to be positive. Milk samples were cultured on the Brucella selective medium and incubated for 24-48 h. One-quarter of milk samples were contaminated with Brucella, which is considered as a relatively high rate of contamination. In addition, biochemical properties of isolates have been identified. All isolated Brucella strains were positive for catalase, oxidase and urea reaction, did not need $\mathrm{CO}_{2}$ to grow and rarely produced $\mathrm{H}_{2} \mathrm{~S}$, could grow in the presence of fuchsin and thionin. The agglutination test was negative with anti-R and positive with anti-M and anti-A sera; so it was determined as $B$. melitensis strain, biovar 3. A specific PCR assay targeting the bcsp31 gene and the specific integration of IS711 elements within the genome of Brucella species has been used. Molecular typing results were compatible with conventional methods.
\end{abstract}

Key words: agglutination test, biochemical test, cow herds, milk ring test

\section{INTRODUCTION}

The term brucellosis is applied to a group of closely related infectious diseases, all caused by Gram-negative bacterial pathogens from the genus Brucella. Phenotypic characteristics, antigenic variation, and prevalence of infection in different animal hosts have resulted in the initial recognition of six species: B. melitensis, B. suis, $B$. abortus, B. canis, B. ovis and B. neotomae (Vizcaino et al., 2004). In addition, in the 1990s, new brucellae have been isolated from marine mammals and a new species, Brucella marins was proposed (Nymo et al., 2011). Manifestations of the disease may range from abortion in the cow to orchitis or epididymitis in the bull (Dougherty et al., 2013). This disease is transmitted by direct or indirect contact with infected excreta. The most important 
routes of transmission are the oral and venereal ones.

B. melitensis infections are widespread worldwide, particularly in the Mediterranean countries, including Syria (Safi et al., 2013). B. melitensis is a small Gramnegative coccobacillus that occurs invariably in the smooth phase, does not require $\mathrm{CO}_{2}$, is catalase and oxidase positive and does not produce $\mathrm{H}_{2} \mathrm{~S}$ or no more than a trace (Ali et al., 2013). It hydrolyses urea and grows in the presence of basic fuchsin or thionin, at the standard concentrations. It has three recognised biovars that are typed on the basis of biochemical tests and serological reactivity (Ali et al., 2014). The economic importance of brucellosis requires the use of sensitive and rapid diagnostic methods. At present, the diagnosis of brucellosis in live dairy cattle involves either the isolation of Brucella from milk samples or the detection of anti-Brucella antibodies in milk (Hamdy \& Amin, 2002). Recently, polymerase chain reaction (PCR)-based detection of organisms has been found to be more convenient as compared to cultural isolation. PCR is an option for brucellosis diagnosis; however, a few studies have been carried out with field samples in a way to use the reaction as a diagnostic tool (O'Leary et al., 2006). AMOS (from the initial letters of abortus, melitensis, ovis and suis) PCR assay can identify $B$. abortus, B. suis, B. melitensis, B. ovis (Bricker et al., 2003).

The aim of the present study was to evaluate the species and biovar of Brucella strains isolated from bovine milk samples collected from Syrian provinces over a period of 6 years using conventional biotyping and specific PCR for the differentiation of Brucella species.

\section{MATERIALS AND METHODS}

\section{Milk samples}

A total of 2372 milking cows were sampled between 2002 and 2007 from 140 cattle herds with abortion history in all Syrian provinces. To get the most reliable results, the milk samples $(15 \mathrm{~mL})$ obtained from the animals (in the evening) were kept at $4{ }^{\circ} \mathrm{C}$ overnight. Each milk sample was centrifuged at $2000 \times g$ for 15 min and the cream and deposit were spread on solid selective medium (Anonymous, 2012).

\section{Milk ring test (MRT)}

This test was performed by adding $30 \mu \mathrm{L}$ of antigen (Institute Proquier, Montpellier, France) to $1 \mathrm{~mL}$ volume of whole milk that has been stored for at least $24 \mathrm{~h}$ at $4{ }^{\circ} \mathrm{C}$. The height of milk column in the tube must be at least $25 \mathrm{~mm}$. A positive reaction was indicated by the formation of a blue ring above a white milk column or at the milk-cream interface. The test was considered to be negative if the ring does not appear and the colour of milk becomes blue.

\section{Bacterial culture}

For the isolation, identification and typing of Brucella spp., 2YTA (20 g agar, $10 \mathrm{~g}$ peptone, $5 \mathrm{~g}$ sodium chloride, $5 \mathrm{~g}$ meat extract, $1 \mathrm{~L}$ distilled water) plates with $5 \%$ sterile horse serum, polymyxin B (5 $\mathrm{U} / \mathrm{mL})$, bacitracin $(25 \mathrm{U} / \mathrm{mL})$ and cycloheximide $(100 \mu \mathrm{g} / \mathrm{mL})$ were used (Parlak et al., 2013). To prepare solid selective media, the basal medium was melted and then cooled to $56{ }^{\circ} \mathrm{C}$ in a water bath and stock solutions of the antibiotics were added. Plates were placed in an incubator for $48 \mathrm{~h}$ at $37{ }^{\circ} \mathrm{C}$ with $10 \% \mathrm{CO}_{2}$ tension adjusted automatically. Bacterial strains were stored in Brucella broth (BD, Spark, 
USA) at $-20{ }^{\circ} \mathrm{C}$ until susceptibility testing.

\section{Identification of Brucella isolates}

Typing of Brucella isolates was made according to the $\mathrm{CO}_{2}$ requirement, $\mathrm{H}_{2} \mathrm{~S}$ production, growth in the presence of dyes (thionin and basic fuchsin), and reaction with monospecific sera anti-A, anti-M and anti-R (Parlak et al., 2013). The laboratory personnel working with these isolates wore impermeable protective clothing, gloves, and a face mask during contact with the organism.

\section{Agglutination reaction}

An isolated colony have been mixed with a monospecific sera anti-A and anti-M or anti-R (ARCOMEX, Amman, Jordan) on a clean glass slide, agitated gently for $30 \mathrm{~s}$ and examined for agglutination.

\section{Bacterial DNA extraction}

Brucella DNA was extracted using proteinase $\mathrm{K}$ and sodium dodecyl sulfate method. The DNA was purified twice with phenol-chloroform using Phase Lock Gel Heavy tubes (Eppendorf AG, Hamburg, Germany). The DNA was also precipitated and washed, and the pellet was resuspended in $50 \mu \mathrm{L}$ of nuclease-free water. Two hundred nanograms of DNA template were used afterwards for PCR amplifications.

\section{Brucella genus-specific DNA amplification}

To diagnose the Brucella positive samples, the first PCR amplification was carried out using primers (Table 1) designed to target the $b c s p 31$ gene (B4/B5) which encodes an immunogenic membrane protein of a $31 \mathrm{kDa}$ antigen of $B$. abortus and is conserved in all Brucella biovars (Baily et al., 1992). All the primers were obtained from AECS, Damascus, Syria. PCR was performed in a $25 \mu \mathrm{L}$ mixture containing template DNA; PCR buffer (10 $\mathrm{mM}$ Tris $\mathrm{HCl}$ with $\mathrm{pH} 8.4,50 \mathrm{mM} \mathrm{KCl}$, $1.5 \mathrm{mM} \mathrm{MgCl} 2)$; 10 pmoL of each primer; $200 \mu \mathrm{M}$ (each) of dATP, dCTP, dTTP and dGTP (Bioline, Inc.), and 1.25 $\mathrm{U}$ of Taq polymerase (Qiagen, Chatsworth, NJ, USA). The cycle consisted of a preheating step at $95{ }^{\circ} \mathrm{C}$ for $5 \mathrm{~min}$ followed by 35 cycles of $90^{\circ} \mathrm{C}$ for $1 \mathrm{~min}, 60^{\circ} \mathrm{C}$ for $30 \mathrm{~s}$, and $72{ }^{\circ} \mathrm{C}$ for $1 \mathrm{~min}$ with a final incubation at $72{ }^{\circ} \mathrm{C}$ for $10 \mathrm{~min}$. Twenty percent of each PCR product was visualised on a $1 \%$ agarose gel stained with $2 \mu \mathrm{g} / \mathrm{mL}$ of ethidium bromide.

Species-specific Brucella DNA amplification

All samples that tested positive using the B4/B5 primers were subjected to second PCR to determine which Brucella species might have caused the infection. The sequences of primers used in the study are listed in Table 1. Species-specific DNA

Table 1. Oligonucleotide primers used in this study

\begin{tabular}{llc}
\hline Target gene & Sequence 5'-3' & Product size (bp) \\
\hline bcsP31- B4 & TGG CTC GGT TGC CAA TAT CAA & 223 \\
bcsP31- B5 & CGC GCT TGC CTT TCA GGT CTG & \\
IS711-B. abortus $-\mathrm{F}$ & CAT GCG CTA TGT CTG GTT AC & 113 \\
IS711-B. abortus $-\mathrm{R}$ & GGC TTTTCT ATC ACG GTA TTC & \\
IS711-B. melitensis-F & AGT GTT TCG GCT CAG AAT AAT C & 252 \\
IS711- B. melitensis $-\mathrm{R}$ & ACC GGA ACA TGC AAA TGA C & \\
\hline
\end{tabular}


segments of B. abortus and B. melitensis were targeted for amplification using specific primers derived from the IS711 element (Baily et al., 1992; Bricker et al., 1994). Amplification conditions were the same as for the first PCR, except for the use of an annealing temperature of $58{ }^{\circ} \mathrm{C}$. A positive control based on DNA from a B. abortus 2308 and B. melitensis 16M references strains was included in all tests, as well as a negative control containing DNA from Yersinia enterocolitica $\mathrm{O} 9$ and E. coli $\mathrm{O} 157$. PCR products were visualised on a $1 \%$ agarose gel as previously described.

\section{RESULTS}

Table 2 shows that MRT was positive in $57 \%$ of cases (1352 out of 2372 bovine milk samples). The number of milk samples contaminated with Brucella after culturing was 596 (25\%), and this percentage is considered relatively high.

Table 2. Conventional methods (milk ring test and culture on Brucella selective medium) and PCR results of testing bovine milk samples $(\mathrm{n}=2372)$

\begin{tabular}{llc}
\hline Method & & Number $(\%)$ \\
\hline \multirow{2}{*}{ MRT } & negative & $1020(43 \%)$ \\
& positive & $1352(57 \%)$ \\
\hline \multirow{2}{*}{ Culture } & negative & $1776(75 \%)$ \\
& positive & $596(25 \%)$ \\
\hline \multirow{2}{*}{ PCR } & negative & $1776(75 \%)$ \\
& positive & $596(25 \%)$ \\
\hline
\end{tabular}

Our results demonstrate that the isolates belonged to $B$. melitensis biovar 3 since they are catalase and oxidase positive, produced a trace of $\mathrm{H}_{2} \mathrm{~S}$ when grown on recommended media; could hydrolyse urea. They could grow in the presence of basic fuchsin or thionin at standard con- centrations and without needing supplementary $\mathrm{CO}_{2}$. All bacterial isolates contained smooth surface antigens and reacted in agglutination reactions with the anti-A and anti-M antibodies only (no reaction with anti-R antibodies).

To confirm our results, all bacteria grown on solid selective media were subjected to Brucella genus amplification using specific primers that amplify a conserved region in Brucella. Agarose gel electrophoresis of the $b c s 31$ conventional PCR amplification gave a product with size of $223 \mathrm{bp}$, indicating the presence of Brucella genus in milk sample (Fig. 1). The PCR control of the Brucella reference strain amplified a product of a similar size. No amplification was detected in the negative control subjects ( $Y$. enterocolitica O:9; and E. coli O157). No cow brucellosis was detected in the samples which were negative in the MRT (results are not presented).

The DNA from Brucella positive milk samples was subjected to the speciesspecific PCR. The second PCR electrophoresis results are shown in Fig. 1, which illustrates the 113 bp and 252 bp bands specific for B. abortus and B. melitensis, respectively. Among the milk samples, we detected only B. melitensis (100\%). B. abortus, $Y$. enterocolitica and $E$. coli O157 were not detected in any of the samples. These results confirmed the specificity and sensitivity of these primers for the targeted region in Brucella DNA.

\section{DISCUSSION}

The epidemiological surveillance of human and animal brucellosis is among the methods considered as a high priority and of essential strategic importance for endemic countries. The Food and Agricultural Organization, the World Health Or- 


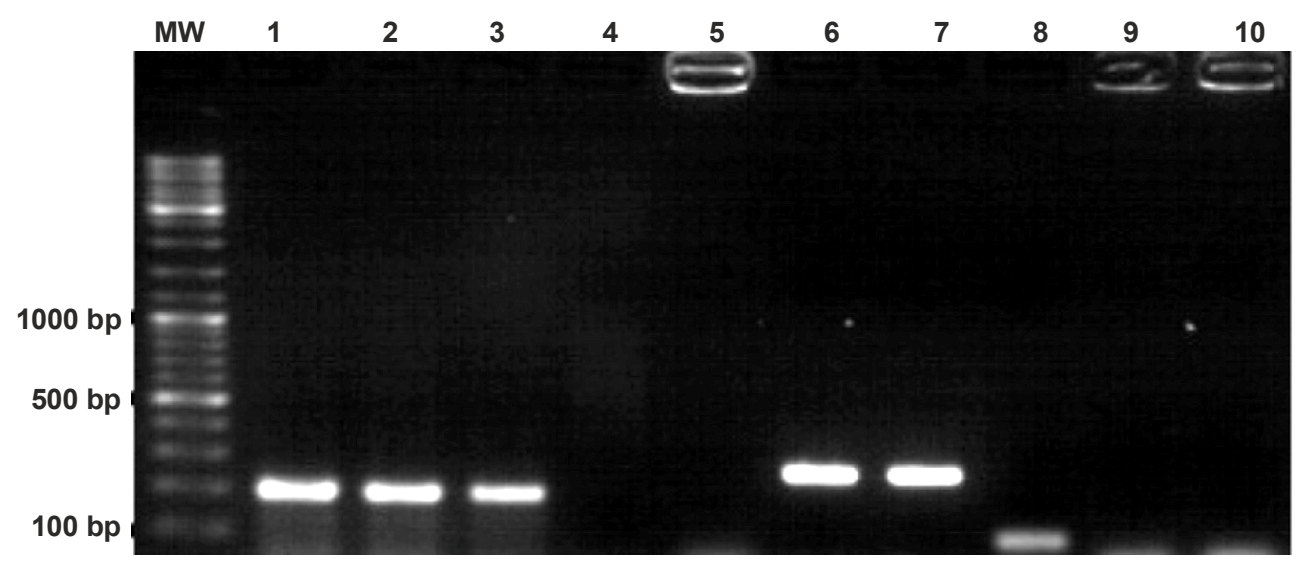

Fig. 1. Agarose gel electrophoresis of PCR assay products. Lane MW: 100 bp ladder (HyperLadder, Bioline, Inc., MA, USA); lanes 1 and 6: B. melitensis 16M reference strain (223 bp); lane 2: B. abortus 2038 reference strain (223 bp); lane 3: B. melitensis from bovine milk sample (223 bp); lanes 4 and 9: $Y$. enterocolitica O:9; lanes 5 and 10: E. coli O157; lane 7: B. melitensis from bovine milk sample (252 bp), lane 8: B. abortus 2038 reference strain (113).

ganization and the World Organisation for Animal Health consider brucellosis as the most widespread zoonosis in the world because it has long been established among livestock in all countries of North Africa and the Middle East including Syria (Anonymous, 2009). The importance of this highly contagious disease is due to: (1) appreciable economic losses caused to the livestock industry in infected areas resulting from abortions, sterility, decreased milk production, veterinary care costs and the cost of culling and replacing animals; and (2) the severe hazard to human health, through either direct contact with infected animals or, more frequently, the consumption of contaminated milk and dairy products (Adone \& Pasquali, 2013).

Currently, the diagnosis of brucellosis in bovine milk sample is based almost entirely on milk ring test, which indirectly detects the brucellosis in the host (Abdalla $\&$ Hamid, 2012). Numerous studies have shown that the MRT can be used to scan a herd of animals, and further demonstrated that such reaction possesses sufficient sensitivity and specificity to diagnose Brucella in a single animal (Trangadia et al., 2010). In other words, bacteria isolation is necessary to determine whether the animal itself is infected with $B$. melitensis, or it contains only antibodies against such bacteria. The most reliable and the only unequivocal method for the diagnostic of animal brucellosis is based on the isolation of Brucella spp. Therefore, the isolation of $B$. melitensis on appropriate culture media is recommended for an accurate diagnosis (Traxler et al., 2013).

PCR is an option for brucellosis diagnosis; however a few studies have been carried out with field samples in a way to use the reaction as a diagnostic tool (Marianelli et al., 2007). In Syria, in spite of the importance of bovine brucellosis, it is important to determine the different Brucella biovars among bovines. Therefore, this experiment analysed the presence of $B$. melitensis in milk from the Syrian provinces using microbiological culture, biochemical test and PCR. 
We describe a PCR assay that can distinguish $B$. melitensis from $B$. abortus. The assay exploits the polymorphism arising from species-specific localisation of the genetic element IS711 in the Brucella chromosome. Identity is determined by the size(s) of the product(s) amplified from primers hybridising at various distances from the element. Tow closely related bacteria ( $Y$. enterocolitica $0: 9$ and E. coli O157) have been tested negative by the assay. Primer pairs used to identify Brucella spp. at the genus-specific level include the primers for sequences encoding BCSP 31(B4/B5) (Baily et al., 1992), 16SrRNA(F4/R2) (Romero et al., 1995), 16s-23S 16S-23S intergenic transcribed spacers (ITS) (Bru ITS-S/Bru ITS-A) (Bricker et al., 2000), 16S-23S rDNA interspace (ITS66/ITS279) (Keid et al., 2007), IS711 (IS313/IS639) (Hénault et al., 2000), per (bruc1/bruc5) (Bogdanovich et al., 2004), omp2 (JPF/JPR) (LealKlevezas et al., 1995), outer membrane proteins (omp 2b, omp2a and omp31) (Imaoka et al., 2007), proteins of the omp25/omp31 family of Brucella spp. (Vizcaino et al., 2004), and arbitrary primers. In this study, the infection was diagnosed using multiple PCR assay, in addition to the conventional methods (biochemical and cultural tests). The assay described in the present study has several advantages over the conventional methods to identify $B$. melitensis infection. A major advantage is the speed with which the assay can be performed, i.e. within a day. The cultural methods require at least several days. Another major advantage of the multiple PCR assay is that no live Brucella organisms are necessarily applied in this assay. This is important because $B$. melitensis is a human pathogen.

The identification of $B$. melitensis biovar level is currently performed by 4 main tests; i.e., $\mathrm{CO}_{2}$ dependence, production of hydrogen sulphide, dye (thionin and basic fuchsin) sensitivity, and agglutination with monospecific $\mathrm{A}$ and $\mathrm{M}$ anti-sera (Fiori et al., 2000). Smooth B. melitensis strains are classified into three serotypes: biovar $1(\mathrm{~A}-\mathrm{M}+)$, biovar $2(\mathrm{~A}+\mathrm{M}-)$, and biovar 3 $(\mathrm{A}+\mathrm{M}+)$, according to slide agglutination with $\mathrm{A}$ and $\mathrm{M}$ monospecific polyclonal anti-sera (Liu et al., 2012). This study indicated that bacterial isolates from bovine milk belonged to $B$. melitensis biovar 3. Moreover, Darwish \& Bemkerias (2001) reported that the Syrian Brucella isolates (between 1990-1996) belonged to $B$. melitensis biovars 2 and 3 in sheep and to $B$. abortus biovar 9 in cattle. In previous biotyping studies in the Middle East (Turkey, Egypt and Jordan), it has been shown that the most common variant was B. melitensis biovar 3 using both conventional and molecular methods, (Şimşek et al., 2004; Samaha et al., 2008; Iça et al., 2012).

Sheep and goats and their products remain the main source of infection, but $B$. melitensis in cattle has emerged as an important problem in Syria (FAO, 1998).

Most cattle and sheep farms in Syria do not have adequate hygiene precautions, and these animals live in a natural environment together with people (Al-Mariri et al., 2011). In Syria, the sheep production system was based on seasonal movement between the rangelands in the east and southeast, and the dry and irrigated cropping areas in the west where the sheep are grazed on crop residues. This sheep movement allows them to contact cows in Syria farms (FAO, 1998). Therefore, we believe that the prevalence of $B$. melitensis among sheep is the reason behind the infection of cows with $B$. melitensis. In addition, there is another factor to such infection namely the conventional 
grazing which is still the prevailing method in Syria, and which increases the percentage of contamination with Brucella after each abortion case. Bovine B. melitensis infection is emerging as an increasingly serious public health problem because $B$. abortus vaccines (S19) do not protect effectively against $B$. melitensis infection (Lucero et al., 2006). Moreover, this strain does not lose its pathogenicity in cattle (Liu et al., 2012). B. melitensis is highly virulent and causes higher abortion rates in cattle and camels and a much more severe human disease than $B$. abortus, the usual agent affecting cattle (Liu et al., 2012). Thus we believe that cows must be vaccinated with Rev. 1 vaccine instead of S19 vaccine because it is more effective against $B$. melitensis. Until now, $B$. melitensis Rev.1 vaccine has not been perfectly evaluated for use in cattle, and therefore there are now difficulties in some countries to entirely eradicate the Brucella infection.

In conclusion, this study was designed to evaluate MRT, conventional technique and PCR to detect brucellosis in milk, collected from Syrian cow herds. B. melitensis was detected in $1352(57 \%)$ out of 2372 milk samples by MRT, while only $596(25 \%)$ samples were positive by both bacteriological isolation methods and PCR. The findings indicated the sensitivity and the specificity of the PCR assay as a useful tool for the rapid diagnosis of $B$. melitensis in bovine milk.

\section{ACKNOWLEDGEMENTS}

The author would like to thank the Director General of AECS, and the head of the Molecular Biology and Biotechnology Department for their support.

\section{REFERENCES}

Al-Mariri, A., L. Ramadan \& R. Akel, 2011. Assessment of milk ring test and some serological tests in the detection of Brucella melitensis in Syrian female sheep. Tropical Animal Health and Production, 43, 865 870.

Anonymous, 2009. The Center for Food Security and Public Health (CFSPH). Brucellosis factsheet. http://www.cfsph. iastate.edu/ Factsheets/pdfs/brucellosis.pdf (24 November 2014 date last accessed).

Anonymous, 2012. World Organisation for Animal Health (OIE). Chapter 2.04.03 Bovine brucellosis. Manual of diagnostic tests and vaccines for terrestrial animals. http://www.oie.int/fileadmin/Home/eng/He alth_standards/tahm/2.04.03_BOVINE_B RUC̄ELL.pdf (24 November 2014 date last accessed).

Adone, R. \& P. Pasquali, 2013. Epidemiosurveillance of brucellosis. Revue scientifique et technique (International Office of Epizootics), 32, 199-205.

Abdalla, A. \& M. E. Hamid, 2012. Comparison of conventional and non-conventional techniques for the diagnosis of bovine brucellosis in Sudan. Tropical Animal Health and Production, 44, 1151-1155.

Ali, S., Q. Ali, H. Neubauer, F. Melzer, M. Elschner, I. Khan, E. N. Abatih, N. Ullah, Irfan M. \& S. Akhter, 2013. Seroprevalence and risk factors associated with brucellosis as a professional hazard in Pakistan. Foodborne Pathogens and Disease, 10, 500-505.

Ali, S., Q. Ali, F. Melzer, I. Khan, S. Akhter, H. Neubauer \& S. M. Jamal, 2014. Isolation and identification of bovine Brucella isolates from Pakistan by biochemical tests and PCR. Tropical Animal Health and Production, 46, 73-78.

Baily, G. G., J. B. Kranhn, B. S. Drasar, \& N. G. Stoker, 1992. Detection of Brucella melitensis and Brucella abortus by DNA amplification. Journal of Tropical Medicine and Hygiene, 13, 271-275. 
Bricker, B. J. \& S. M. Halling, 1994. Differentiation of Brucella abortus bv 1, 2, and 4, Brucella melitensis, Brucella ovis, and Brucella suis bv 1 by PCR. Journal of Clinical Microbiology, 13, 2660-2666.

Bricker, B. J., D. R. Ewalt, A. P. MacMillan, G. Foster \& S. Brew, 2000. Molecular characterization of Brucella strains isolated from marine mammals. Journal of Clinical Microbiology, 38, 1258-1262.

Bricker, B. J., D. R. Ewalt, S. C. Olsen \& A. E. Jensen, 2003. Evaluation of the Brucella abortus species specific polymerase chain reaction assay, an improved version of the Brucella AMOS polymerase chain reaction assay for cattle. Journal of Veterinary Diagnostic Investigation, 15, 374-378.

Bogdanovich, T., M. Skurnik, P. S. Lubeck, P. Ahrens, \& J. Hoorfar, 2004. Validated 5' nuclease PCR assay for rapid identification of the genus Brucella. Journal of Clinical Microbiology, 42, 2261-2263.

Darwish, M. \& A. Benkirane, 2001. Field investigations of brucellosis in cattle and small ruminants in Syria, 1990-1996. Revue scientifique et technique (International Office of Epizootics), 20, 769-775.

Dougherty, A. M., T. E. Cornish, D. O'Toole, A. M. Boerger-Fields, O. L. Henderson \& K. W. Mills, 2013. Abortion and premature birth in cattle following vaccination with Brucella abortus strain RB51. Journal of Veterinary Diagnostic Investigation, 25, 630-635.

Food and Agriculture Organization (FAO). 1998. A Perspective of Brucellosis Surveillance in north Africa and the Middle East: Studies in Algeria-Iran-Kuwait-Morocco-Oman-Sudan and Syria. January 1998; GCP/REM/059/IFA. FAO Consultancy mission report.

Fiori, P. L., S. Mastrandrea, P. Rappelli \& P. Cappuccinelli, 2000. Brucella abortus infection acquired in microbiology laboratories. Journal of Clinical Microbiology, 38, 2005-2006.
Gupta, V. K., K. Deepak, P. K. Vermaa, S. V. Routa \& V. S. Vihana, 2006. Polymerase chain reaction (PCR) for detection of Brucella melitensis in goat milk. Small Ruminant Research, 65, 79-84.

Hamdy, M. E. \& A. S. Amin, 2002. Detection of Brucella species in the milk of infected cattle, sheep, goats and camels by PCR. The Veterinary Journal, 163, 299-305.

Hénault, S., D. Calvez, M. Thiébaud, M. Bouliëre \& B. Garin-Bastuji, 2000. Validation of a nested-PCR based on the IS6501/711 sequence for the detection of Brucella in animal samples. In: Proceedings of the Brucellosis 200 International Research Conference 9I including the $53^{\text {rd }}$ Brucelllosis Research Conference; September 7-9; Nimes, France. Paris: INRA; 2000.

Iça, T., A. Fuat, K. S. Gümüşsoy, D. Perçin, A. B. Sümerkan, F. Ocak, S. Abay, H. O. Doğan, A. Findik \& A. Çiftci, 2012. Conventional and molecular biotyping of Brucella strains isolated from cattle, sheep and human. Ankara Üniversitesi Veteriner Fakültesi Dergisi, 59, 259-264.

Imaoka, K., M. Kimura, M. Suzuki, T. Kamiyama \& A. Yamada, 2007. Simultaneous detection of the genus Brucella by combinatorial PCR Japanese. Journal of infectious diseases., 60, 137-139.

Keid, L. B., R. M. Soares, S. A. Vasconcellos, D. P. Chiebao, V. R. Salgado, J. Megid \& L. J. Richtzenhain, 2007. A polymerase chain reaction for detection of Brucella canis in vaginal swabs of naturally infected bitches. Theriogenology, 68, 1260-1270.

Leal-Klevezas, D. S., I. O. Martinez-Vazquez, A. Lopez-Merino \& J. P. MartinezSoriano, 1995. Single-step PCR for detection of Brucella spp. from blood and milk of infected animals. Journal of Clinical Microbiology, 33, 3087-3090.

Liu, W., Z. Jing, Q. Ou, B. Cui, Y. He \& Q. $\mathrm{Wu}, 2012$. Complete genome sequence of Brucella melitensis biovar 3 strain NI, isolated from an aborted bovine fetus. Journal of Bacteriology, 194, 6321. 
Lucero, N. E., S. M. Ayala, G. I. Escobar, M. Grayon, \& I. Jacques, 2006. A new variant of Brucella melitensis. Clinical Microbiology and Infection, 12, 593-596.

Marianelli, C., C. Graziani, C. Santangelo, M. T. Xibilia, A. Imbriani, R. Amato, D. Neri, M. Cuccia, S. Rinnone, V. Di Marco \& F. Ciuchini, 2007. Molecular epidemiological and antibiotic susceptibility characterization of Brucella isolates from humans in Sicily, Italy. Journal of Clinical Microbiology, 45, 2923-2928.

Nymo, I. H., M. Tryland \& J. Godfroid, 2011. A review of Brucella infection in marine mammals, with special emphasis on Brucella pinnipedialis in the hooded seal (Cystophora cristata). Veterinary Research, 5, 93.

O'Leary, S., M. Sheahan \& T. Sweeney, 2006. Brucella abortus detection by PCR assay in blood, milk and lymph tissue of serologically positive cows. Research in Veterinary Science, 81, 170-176.

Parlak, M., H. Güdücüoğlu, Y. Bayram, A. Çıkman, C. Aypak, S. Kılıç \& M. Berktaş, 2013. Identification and determination of antibiotic susceptibilities of Brucella strains isolated from patients in van, Turkey by conventional and molecular methods. International Journal of Medical Sciences, 22, 1406-1411.

Romero, C., C. Gamazo, M. Pardo \& I. LopezGoni, 1995. Specific detection of Brucella DNA by PCR. Journal of Clinical Microbiology, 33, 615-617.

Safi, M., B. Albalaa \& A. Al-Mariri, 2013. Prophylactic efficacy of some antibiotic combinations against Brucella melitensis $16 \mathrm{M}$ in BALB/c mice. Bulgarian Journal of Veterinary Medicine, 16, 198-207.

Samaha, H., M. Al-Rowaily, R. M. Khoudair \& H. M. Ashour, 2008. Multicenter study of brucellosis in Egypt. Emerging Infectious Diseases, 14, 1916-1918.
Şimșek, H., S. Erdenliğ, B. Oral \& N. Tülek, 2004. Determination of type-biotype and epidemiological investigation of Brucella isolates from humans. Klimik Dergisi, 17, 103-106.

Trangadia, B., S. K. Rana, F. Mukherjee, V. A. Srinivasan, 2010. Prevalence of brucellosis and infectious bovine rhinotracheitis in organized dairy farms in India. Tropical Animal Health and Production, 42, 203 207.

Traxler, R. M., M. W. Lehman, E. A. Bosserman, M. A. Guerra \& T. L. Smith, 2013. A literature review of laboratoryacquired brucellosis. Journal of Clinical Microbiology, 51, 3055-3062.

Vizcaino, N., P. Caro-Hernandez, A. Cloeckaert \& L. Fernandez-Lago, 2004. DNA polymorphism in the omp25/omp31 family of Brucella spp.: identification of a 1.7-kb inversion in Brucella cetaceae and of a $15.1-\mathrm{kb}$ genomic island, absent from Brucella ovis, related to the synthesis of smooth lipopolysaccharide. Microbes and Infection, 6, 821-834.

Paper received 09.07.2014; accepted for publication 02.10.2014

\section{Correspondence:}

Dr. Ayman Al-Mariri

Department of Molecular Biology and Biotechnology,

Atomic Energy Commission,

P.O. Box 6091,

Damascus Syria

Tel: +963.11.213580; fax: +963.11.6112289

e-mail: ascientific@aec.org.sy 